Jurnal Akuntansi dan Keuangan (JAK)

Volume 5, Nomor 2 Tahun 2020

Page: 307 - 317

http://ojs.uho.ac.id/index.php/jak-uho

e-ISSN: 2088-4656

\title{
ANALISIS BIAYA KUALITAS DALAM UPAYA MENGURANGI PRODUK CACAT PADA PT. FAJAR UTAMA INTERMEDIA KENDARI
}

\section{Oleh:}

\author{
Andi Basru Wawo ${ }^{1}$ Emillia Nurdin ${ }^{2}$, Mildayanti ${ }^{3}$
}

Email : milda.yanti21@gmail.com

\begin{abstract}
ABSTRAK
Penelitian ini bertujuan untuk mengetahui penggunaan biaya kualitas yang dikeluarkan oleh perusahaan dalam upaya mengurangi produk cacat pada PT. Fajar Utama Intermedia. Penelitian ini menggunakan data kualitatif dan kuantitatif dan alat analisis yang digunakan adalah analisis deskriptif. Hasil penelitian menunjukkan penggunaan biaya kualitas yang dikeluarkan oleh perusahaan rata-rata perbulannya ialah sebesar Rp 17.410.0 atau hanya $0,84 \%$ dari total penjualan sebesar $\mathrm{Rp} 2.080 .000 .000 /$ bulan. Dimana pendapatan $\mathrm{Rp}$ 2.080.000.000 ini didapatkan dari rata-rata penjualan koran sebanyak 20.000 eksemplar/hari dengan harga penjualan satu eksemplar sebesar Rp 4.000,-. Adapun biaya kualitas yang dikeluarkan PT. Fajar Utama Intermedia ialah biaya perawatan preventif yang terdiri dari pelumasan seluruh bagian dinamo motor mesin cetak dan inspeksi, biaya penggunaan bahan supplies yang terdiri dari pelumasan mesin dan bahan bakar generator serta biaya sisa bahan baku yang terdiri dari pemborosan kertas dan tinta. Berdasarkan penelitian tersebut, perusahaan perlu menyusun laporan biaya kualitas kemudian mengambil tindakan dengan meningkatkan biaya pencegahan dan biaya penilaian dengan mengalokasikan sejumlah biaya pada kedua hal tersebut sehingga akan menurunkan jumlah produk cacat dan membuat biaya kegagalan menjadi semakin rendah. Kata Kunci : Biaya Kualitas, Produk cacat
\end{abstract}

\section{ABSTRACT}

This study aims to determine the use of quality costs incurred by the company in an effort reduce product defects at PT. Fajar Utama Intermedia. The data of this study used qualitative data and quantitative data and the analysis method used descriptive analysis. The result showed that the use of quality costs incurred by companies on average about IDR 17.410 .000 per month or only $0.84 \%$ of the total sales IDR 2.080.000.000/month. Where the amount of income IDR 2.080.000.000 was obtained from the average of newspaper sales of 20.000 copies per day with the sales price about IDR 4.000,-. The quality cost incurred by PT. Fajar Utama Intermedia is the cost of preventive maintenance consisting of lubrication of all parts of the motor dynamo of printing and inspection machines, the cost of using supplies which consist of lubricating the engine and generator fuel as well as the cost of remaining raw materials consisting of waste paper and ink. Based on this study, the company needs to prepare a quality cost report and then take an action by increasing the cost of prevention and appraisal costs by allocating of costs to both of these so that it will reduce of defect product and make the cost of failure even lower.

Keywords: Quality Cost, Product Defects.

\section{PENDAHULUAN}

Dalam era industrialisasi yang semakin kompetitif sekarang ini, setiap perusahaan dituntut untuk dapat ikut serta dalam persaingan. Kompetisi yang semakin ketat ini secara langsung memberikan tekanan kepada perusahaan untuk meningkatkan kualitas 
produknya baik itu barang maupun jasa dalam upaya meningkatkan kepuasan pelanggan. Salah satu usaha yang dapat dilakukan perusahaan untuk bersaing adalah dengan menghasilkan produk yang dapat memberikan nilai tambah baik dari segi manfaat maupun segi kualitas (Susilowati, 2011:16). Sedangkan untuk dapat bertahan, suatu perusahaan harus dapat mempertahankan kualitas dari produk yang dihasilkannya. Dengan hasil produksi yang berkualitas, maka diharapkan para pelanggan atau konsumen akan tertarik dan membeli hasil produksi yang ditawarkan oleh perusahaan.

Menurut Hansen dan Mowen (20013:5), kualitas adalah derajat atau tingkat kesempurnaan, dalam hal ini kualitas merupakan ukuran relatif dari kebaikan. Secara operasional, produk atau jasa yang berkualitas adalah yang memenuhi atau melebihi harapan pelanggan. Untuk memenuhi harapan pelanggan tersebut dapat dilihat dalam beberapa segi ukuran kualitas yaitu kinerja, estetika, kemudahan perawatan dan perbaikan, fitur, keandalan, tahan lama, kualitas kesesuaian dan kecocokkan penggunaan.

Perusahaan PT. Fajar Utama Intermedia merupakan perusahaan manufaktur yang bergerak dalam bidang percetakan surat kabar yang terus berupaya untuk meningkatkan kualitas dan kuantitas produk yang dihasilkannya agar dapat memenuhi harapan pelanggan. Koran yang dicetak oleh perusahaan ini yaitu, Kendari Pos, Rakyat Sultra, Kolaka Pos, Radar Buton dan Berita Kota.

Perusahaan tersebut terus berupaya mengembangkan metode untuk dapat menghilangkan produk defect dan dalam upaya menghasilkan produk yang baik dan sesuai dengan standar kualitas yang ditetapkan. Akan tetapi pada kenyataannya masih terdapat produk yang kualitasnya tidak sesuai standar. Data jumlah produksi beserta produk cacat (defect) pada tahun 2019 dapat dilihat pada tabel berikut ini:

Tabel 1. Kerusakan Produk dan Produk Cacat

PT. Fajar Utama Intermedia Bulan September Tahun 2019

\begin{tabular}{|c|l|c|c|c|c|c|}
\hline No & $\begin{array}{l}\text { Jenis } \\
\text { Media }\end{array}$ & $\begin{array}{c}\text { Jumlah } \\
\text { Kerusakan Produk } \\
(\mathrm{Kg} / \text { hari })^{*}\end{array}$ & $\begin{array}{c}\text { Jumlah } \\
\text { Produk Cacat } \\
(\text { Eksemplar })\end{array}$ & $\begin{array}{c}\text { Harga Per } \\
\text { Eksemplar } \\
(\mathrm{Rp})\end{array}$ & $\begin{array}{c}\text { Jumlah Harga } \\
\text { Kerusakan } \\
\text { Perhari (Rp) }\end{array}$ & $\begin{array}{c}\text { Jumlah Harga } \\
\text { Perbulan } \\
(\mathrm{Rp})\end{array}$ \\
\hline 1. & Kendari Pos & 35 & 280 & 4.000 & 1.120 .000 & 29.120 .000 \\
\hline 2. & Rakyat Sultra & 15 & 120 & 4.000 & 480.000 & 12.480 .000 \\
\hline 3. & Kolaka Pos & 12 & 96 & 4.000 & 384.000 & 9.984 .000 \\
\hline 4. & Radar Buton & 12 & 96 & 4.000 & 384.000 & 9.984 .000 \\
\hline 5. & Berita Kota & 9 & 72 & 4.000 & 288.000 & 7.488 .000 \\
\hline & Jumlah & 83 & 664 & & 2.656 .000 & 69.056 .000 \\
\hline
\end{tabular}

Sumber: Data Primer yang diolah 2019

Keterangan:

*)Satu kilogram terdiri dari delapan eksemplar.

Dari data tersebut dapat dilihat bahwa biaya kerusakan terbesar adalah untuk pembuatan koran Kendari Pos sebesar Rp 1.120.000/hari, diikuti oleh Rakyat Sultra sebesar Rp 480.000/hari, Kolaka Pos dan Radar Buton sebesar masing-masing Rp 384.000/hari, dan yang terkecil adalah Berita Kota sebesar Rp 288.000/hari. Jadi jumlah kerusakan per hari rata-rata sebesar Rp 2.656.000,00 atau sebanyak 664 eksemplar/hari.

Dalam proses produksinya, PT. Fajar Utama Intermedia masih terdapat sejumlah produk yang cacat atau tidak sesuai dengan standar produksi, jika produk cacat tersebut jumlahnya terus meningkat maka dapat berdampak pada peningkatan harga pokok produksi per unit barang. Hal ini akan berdampak buruk pada tingkat persaingan di dunia usaha, sehingga untuk mengatasi masalah tersebut, perusahaan harus dapat menekan jumlah produk cacat seminimal mungkin. Alternatif yang dapat digunakan perusahaan dalam mengendalikan jumlah produk cacat yaitu dengan mengeluarkan biaya kualitas. 
Melalui analisis biaya kualitas dapat diketahui berapa jumlah biaya yang dikeluarkan perusahaan dalam suatu pengendalian kualitas produk dan kegiatan apa saja yang dilakukan perusahaan untuk mengefisienkan biaya tanpa menurunkan kualitas produk yang dihasilkan. Perusahaan yang melakukan pencegahan terhadap timbulnya produk cacat akan mampu membuat biaya produksi lebih efisien, karena perusahaan tidak perlu menurunkan harga jual untuk alasan produk cacat dan tidak perlu melakukan pengerjaan ulang terhadap produk cacat tersebut, sehingga bahan baku dan tenaga kerja dapat digunakan seefisien mungkin (Susilowati, 2011:6).

Penelitian ini bertujuan untuk mengetahui dan menganalisis penggunaan biaya kualitas yang dikeluarkan untuk mengurangi produk cacat pada PT. Fajar Utama Intermedia.

\section{LANDASAN TEORI}

\section{Biaya}

Harnanto, (2017:22) mendefinisikan biaya atau cost adalah pengorbanan sumber daya ekonomi yang diukur dalam satuan uang yang telah terjadi atau kemungkinan telah terjadi untuk tujuan tertentu.

Menurut Supriyono (2011:14) Biaya adalah harga perolehan yang dikorbankan atau digunakan dalam rangka memperoleh penghasilan dan akan dipakai sebagai pengurang penghasilan. Sedangkan menurut William Carter (2009:30) biaya sebagai suatu nilai tukar, pengeluaran, atau pengorbanan yang dilakukan untuk menjamin perolehan manfaat. Dalam akuntansi keuangan, pengeluaran atau pengorbanan pada tanggal akuisisi dicerminkan oleh penyusutan atas kas atau asset lain yang terjadi pada saat ini atau dimasa yang akan datang. Biaya dapat diartikan sebagai pengorbanan sumber ekonomi yang perlu dilakukan untuk suatu proses produksi yang dapat diukur dalam satuan uang baik yang telah terjadi atau akan terjadi untuk mencapai tujuan tertentu.

Indikator dari definisi biaya diatas yaitu:

1. Biaya merupakan pengorbanan sumber ekonomi.

2. Diukur dalam satuan uang.

3. Yang telah terjadi atau secara potensial akan terjadi.

4. Pengorbanan tersebut untuk tujuan tertentu

Penggolongan biaya menurut Supriyono (2011:16) penggolongan adalah proses pengelompokkan atas seluruh elemen yang ada ke dalam golongan-golongan tertentu, yang lebih ringkas untuk dapat memberikan informasi biaya yang lebih berarti. Sedangkan Penggolongan Biaya Menurut Mulyadi (2015:13), biaya dapat digolongkan berdasarkan pada:

1. Obyek pengeluaran

2. Fungsi pokok dalam perusahaan

3. Hubungan biaya dengan sesuatu yang dibiayai

4. Berdasakan hubungannya dengan volume kegiatan

5. Jangka waktu manfaatnya

Biaya Kualitas

Menurut Samryn (2012:306), biaya kualitas (cost of quality) adalah biaya yang terjadi atau mungkin akan terjadi karena kualitas yang buruk. Krismiaji dan Aryani (2011:390) menyatakan bahwa biaya kualitas adalah biaya yang terjadi karena kualitas produk yang dihasilkan rendah. Biaya kualitas adalah biaya yang timbul berkaitan dengan upaya mengubah produk bermutu buruk (bad quality product) menjadi produk yang bermutu baik (good quality product). Biaya kualitas adalah biaya yang dikeluarkan oleh perusahaan untuk memperbaiki kualitas produk atau untuk mencapai standar yang telah ditetapkan. Biaya kualitas perlu dikelola sedemikian rupa untuk mencapai suatu tingkat 
kualitas agar produk yang dibuat atau jasa yang diserahkan sesuai dengan spesifikasi rancangan dan bebas dari cacat . Biaya kualitas dikelompokan menjadi empat kategori yaitu: biaya pencegahan, biaya penilaian, biaya kegagalan internal dan biaya kegagalan ekternal.

Horngren, (2008:288) menyatakan bahwa komponen biaya kualitas dapat diklasifikasikan ke dalam 4 klasifikasi, yaitu:

a. Biaya pencegahan (Prevention cost) Biaya pencegahan terjadi untuk menghindari kualitas yang buruk. Biaya pencegahan adalah biaya yang terjadi untuk menghalangi produksi dari produk yang tidak memenuhi spesifikasi. Item biaya pencegahan antara lain biaya rencangan desain, rancangan proses, pemeliharaan perlengkapan, pencegahan, dan pelatihan kualitas. Biaya pencegahan apabila naik maka diharapkan cost of failure turun. Dengan demikian biaya pencegahan dikeluarkan untuk menurunkan jumlah produk yang tidak memenuhi syarat (nonconforming unit).

b. Biaya penilaian (appraisal cost) Biaya penilaian sebagai biaya yang terjadi untuk mendeteksi unit individu mana yang tidak memenuhi spesifikasi. Contohnya biaya inspeksi dan biaya pengujian produk.

c. Biaya kegagalan internal (internal failure cost) Biaya kegagalan internal adalah biaya yang terjadi pada suatu produk yang cacat sebelum dikirim ke pelanggan. Contohnya yaitu biaya cacat produksi, pengerjaan kembali, biaya sisa.

d. Biaya kegagalan eksternal (eksternal failure cost) Biaya kegagalan eksternal yaitu biaya yang dikeluarkan untuk memperbaiki kerusakan kualitas setelah produk atau jasa yang tidak dapat diterima mencapai pelanggan. Contoh biaya kegagalan eksternal yaitu biaya penanganan keluhan dan klaim pelanggan, biaya penggantian garansi, biaya perbaikan dan ongkos kirim produk yang dikembalikan, biaya tuntutan lebih jauh dari pelanggan karena menerima produk yang tidak memenuhi standar kualitas.

Sebagai langkah awal dalam program perbaikan kualitas, perusahaan menyusun laporan biaya kualitas yang memberikan sebuah perkiraan adanya konsekuensi keuangan dari tingkat cacat produk yang ada di perusahaan. Pentingnya biaya kualitas untuk segi keuangan perusahaan dapat lebih mudah dinilai dengan menampilkan biaya-biaya kualitas sebagai persentase dan penjual aktual. Feigenbaum, (2013:21) menyatakan Informasi yang ada dalam laporan biaya kualitas secara garis besar memberikan manfaat (1) Sebagai alat untuk mengukur kinerja (2) Sebagai alat analisis mutu proses (3) Sebagai alat pemprograman (4) Sebagai alat penganggaran yaitu untuk membuat anggaran pengeluaran dalam mencapai program pengendali mutu (5) Sebagai alat peramal yaitu untuk mengevaluasi dan menjamin prestasi produk dalam memenuhi persaingan pasar.

Produk Cacat

Menurut Hansen dan Mowen (2009:7), produk cacat adalah produk yang dihasilkan dalam proses produksi namun tidak memenuhi spesifikasinya, tetapi secara ekonomis produk tersebut dapat diperbaiki dengan mengeluarkan biaya tertentu sehingga menjadi produk baik. Menurut Mulyadi (2010:306), produk cacat adalah produk yang tidak memenuhi standar yang telah ditentukan, tetapi dengan mengeluarkan biaya pengerjaan kembali untuk memperbaikinya, produk tersebut secara ekonomis dapat disempurnakan lagi menjadi produk jadi yang baik. Sedangkan menurut Firdaus Ahmad Dunia dan Wasilah (2012:69), barang/produk cacat adalah barang yang tidak memenuhi standar produksi karena kesalahan dalam bahab, tenaga kerja atau mesin dan harus diproses lebih lanjut agar memenuhi standar mutu yang ditentukan, sehingga produk tersebut dapat dijual kembali.

Produk cacat adalah barang atau jasa yang dihasilkan dalam proses produksi, dimana produk yang dihasilkan tersebut tidak sesuai dengan standar mutu yang 
ditetapkan, tetapi secara ekonomis produk tersebut dapat diperbaiki dengan mengeluarkan biaya tertentu. Produk cacat merupakan produk yang tidak dapat diterima oleh konsumen karena produk tersebut tidak sesuai dengan spesifikasi sehingga tidak memenuhi standar kualitas yang telah ditentukan yang menyebabkan nilai atau mutunya kurang baik atau kurang sempurna.

\section{METODE PENELITIAN}

Penelitian ini dilakukan di PT. Fajar Utama Intermedia yang berlokasi di Jalan Malik Raya, No. 50 Kota Kendari Provinsi Sulawesi Tenggara. Adapun yang menjadi objek penelitian ini adalah penggunaan biaya kualitas dalam upaya mengurangi produk cacat pada PT. Fajar Utama Intermedia.

Jenis data yang digunakan dalam penelitian ini yaitu data kuantitatif dan data kualitatif. Data kuantitatif yang digunakan dalam penelitian ini yaitu data yang berupa angka-angka mengenai jumlah produksi dan data produk cacat. Sedangkan data kualitatif dalam penelitian ini yaitu data yang berupa informasi tertulis yaitu informasi mengenai jenis produk cacat, penyebab terjadinya produk cacat, bahan baku yang digunakan serta informasi yang berkaitan dan relevan dengan judul skripsi ini.

Sumber data yang digunakan dalam penelitian ini menggunakan data primer dan data sekunder. Data primer diperoleh melalui wawancara dan pengamatan secara langsung di PT. Fajar Utama Intermedia. Wawancara dilakukan dengan bertemu langsung dengan pihak yang berhubungan dan berkompeten terhadap data yang dibutuhkan oleh peneliti yang dianggap relevan dengan masalah penelitian. Dalam hal ini dengan manajer/karyawan pada bagian keuangan dan bagian operasional cetak pada PT. Fajar Utama Intermedia. Sedangkan data sekunder dalam penelitian ini adalah data berupa dokumen/arsip bagian produksi dan struktur organisasi PT. Fajar Utama Intermedia.

Metode Analisis data yang dilakukan dalam penelitian ini akan dianalisis dengan menggunakan metode analisis deskriptif yaitu dengan cara mengidentifikasi dan mengelompokkan jenis-jenis biaya kualitas berdasarkan metode PAF (Prevetion, Appraisal, and Failure). Menghitung total biaya kualitas, menghitung persentase biaya kualitas dengan cara membandingan total biaya kualitas dengan penjualan, dan menghitung persentase produk cacat dengan cara membandingkan jumlah produk yang cacat dengan jumlah produksi.

\section{HASIL PENELITIAN DAN PEMBAHASAN}

\section{Hasil Penelitian}

Sistem Persediaan Perusahaan

Dalam memenuhi permintaan barang dari perusahaan penerbitan dan didalam melakukan kegiatan produksinya, PT. Fajar Utama Intermedia Cabang Kendari memerlukan bahan baku yang terdiri dari kertas Koran, plate, dan tinta cetak.

\section{Sistem Kerja}

PT. Fajar Utama Intermedia mempunyai lima (5) hari kerja dalam seminggu yaitu mulai hari Senin sampai Jum'at. Sedangkan untuk bagian produksi cetak koran/operator, waktu kerja adalah senin sampai sabtu kecuali hari besar (tanggal merah). Adapun jumlah karyawan bagian operator PT. Fajar Utama Intermedia berjumlah 7 orang bagian proses produksi dan 1 orang bagian pemeliharaan (maintenance).

Bahan Baku dan Mesin

Bahan baku yang digunakan PT. Fajar Utama Intermedia untuk proses produksinya antara lain: 
Jurnal Akuntansi dan Keuangan (JAK)

Volume 5, Nomor 2 Tahun 2020

Page: 307 - 317

http://ojs.uho.ac.id/index.php/jak-uho

e-ISSN: 2088-4656

Tabel 2. Biaya Bahan Baku

\begin{tabular}{|c|l|c|c|c|c|}
\hline No & Bahan Baku & $\begin{array}{c}\text { Harga } \\
\text { Beli }\end{array}$ & $\begin{array}{c}\text { Jumlah Bahan } \\
\text { yang Digunakan }\end{array}$ & $\begin{array}{c}\text { Jumlah } \\
\text { Harga (Rp) }\end{array}$ & $\begin{array}{c}\text { Jumlah Harga } \\
\text { Disatu bulankan (Rp) }\end{array}$ \\
\hline 1. & Tinta Cetak & $\mathrm{Rp} \mathrm{70.000}$ & $20 \mathrm{~kg}$ & $\mathrm{Rp} \mathrm{1.400.000}$ & $\mathrm{Rp} \mathrm{36.400.000}$ \\
\hline 2. & Kertas Koran & $\mathrm{Rp} 12.000$ & $371 \mathrm{~kg}$ & $\mathrm{Rp} \mathrm{4.452.000}$ & $\mathrm{Rp} \mathrm{115.752.000}$ \\
\hline 3. & Plate & $\mathrm{Rp} \mathrm{30.000}$ & 50 lembar & $\mathrm{Rp} 1.500 .000$ & $\mathrm{Rp} \mathrm{39.000.000}$ \\
\hline & Jumlah & & & $\mathrm{Rp} \mathrm{7.352.000}$ & $\mathrm{Rp} \mathrm{191.152.000}$ \\
\hline
\end{tabular}

Sumber : Data primer yang diolah

Penggunaan Biaya Kualitas di PT. Fajar Utama Intermedia

Penggunaan biaya kualitas di PT. Fajar Utama Intermedia terdiri dari perawatan

mesin, penggunaan bahan supplies, dan biaya sisa bahan (scrap).

Laporan Biaya Kualitas pada PT. Fajar Utama Intermedia cab. Kendari

Seluruh hasil perhitungan yang telah dilakukan, akan diringkas dalam bentuk laporan biaya kualitas. Laporan biaya kualitas dapat dilihat pada tabel berikut:

Tabel 3. Laporan Biaya Kualitas

\begin{tabular}{|c|c|c|c|}
\hline Kelompok Biaya Kualitas & \multicolumn{2}{|c|}{ Biaya Kualitas } & Persentase \\
\hline $\begin{array}{l}\text { 1. Biaya Pencegahan (Prevention } \\
\text { Costs) } \\
\text { 1.1 Biaya perawatan atau } \\
\text { Pemeliharaan mesin : } \\
\text { a. Pelumasan dinamo mesin } \\
\text { b. Cleaning dan perbaikan } \\
\text { c. Bahan bakar generator }\end{array}$ & $\begin{array}{l}\text { Rp } 3.840 .000 \\
\text { Rp } 5.000 .000 \\
\text { Rp } 1.000 .000\end{array}$ & & $\begin{array}{l}39,02 \% \\
50,82 \% \\
10,16 \%\end{array}$ \\
\hline Total Biaya Pencegahan & & Rp 9.840.000 & $56,52 \%$ \\
\hline $\begin{array}{l}\text { 2. Biaya Penilaian (Appraisal } \\
\text { Costs) } \\
\text { 2.1 Biaya inspeksi }\end{array}$ & $\mathrm{Rp} 3.840 .000$ & & $100,00 \%$ \\
\hline Total Biaya Penilaian & & Rp 3.840.000 & $22,06 \%$ \\
\hline $\begin{array}{l}\text { 3. Biaya Kegagalan Internal } \\
\text { (Internal Failure Costs) } \\
\text { 3.1. Biaya sisa bahan : } \\
\text { a. Sisa kertas } \\
\text { b. Pemborosan tinta } \\
\end{array}$ & $\begin{array}{l}\mathrm{Rp} 2.400 .000 \\
\mathrm{Rp} 1.330 .000 \\
\end{array}$ & & $\begin{array}{r}64,34 \% \\
35,66 \% \\
\end{array}$ \\
\hline Total Biaya Kegagalan Internal & & Rp 3.730.000 & $21,42 \%$ \\
\hline Total Biaya Kualitas & & Rp 17.410.000 & $100 \%$ \\
\hline
\end{tabular}

Sumber: Data primer yang diolah

Total Biaya Kualitas

Dari data-data yang telah didapat, dapat dihitung besarnya biaya kualitas dari PT.

Fajar Utama Intermedia cab. Kendari. Total biaya kualitas dapat dihitung dengan:

Total Biaya Kualitas = Biaya Pencegahan + Biaya Penilaian + Biaya Kegagalan

$$
\begin{aligned}
& =\operatorname{Rp} 9.840 .000+3.840 .000+3.730 .000 \\
& =\operatorname{Rp} 17.410 .000
\end{aligned}
$$

Persentase Penggunaan Biaya Kualitas

Untuk mengetahui besarnya persentase total biaya kualitas di PT. Fajar Utama 
Jurnal Akuntansi dan Keuangan (JAK)

Volume 5, Nomor 2 Tahun 2020

Page: 307 - 317

http://ojs.uho.ac.id/index.php/jak-uho

e-ISSN: 2088-4656

Intermedia cab. Kendari dapat diukur dengan:

$$
\begin{aligned}
\text { Persentase Biaya Kualitas } & =\frac{\text { Total Biaya Kualitas }}{\text { Penjualan }} \times 100 \% \\
& =\frac{\text { Rp } 17.410 .000}{\operatorname{Rp} 2.080 .000 .000} \times 100 \% \\
& =0,84 \%
\end{aligned}
$$

Berdasarkan hasil wawancara tentang laporan biaya kualitas, rata-rata penjualan di PT. Fajar Utama Intermedia per harinya sebanyak 20.000 eksemplar/hari dengan masa 26 hari kerja dan harga penjualan untuk satu eksemplar sebesar Rp 4.000,sehingga diperoleh total pendapatan rata-rata per bulan perusahaan tersebut sebesar Rp 2.080.000.000. Sementara itu total biaya kualitas yang dikeluarkan perusahaan ialah hanya sebesar $\mathrm{Rp} 17.410 .000$ atau $0,84 \%$ penggunaan biaya kualitas dari total penjualan per bulannya.

Persentase Produk Cacat

Untuk mengetahui besarnya persentase produk cacat dapat diketahui dengan membandingkan jumlah produk yang cacat dengan jumlah produk yang diproduksi.

$$
\begin{aligned}
\text { Persentase Produk Cacat } & =\frac{\text { Jumlah Produk Cacat }}{\text { Jumlah Produksi }} \times 100 \% \\
& =\frac{196.142}{5.664 .160} \times 100 \% \\
& =3,45 \%
\end{aligned}
$$

Besarnya persentase produk cacat yang dimiliki oleh PT. Fajar Utama Intermedia sebesar 3,45\%. Perusahaan memberikan batas persentase produk cacat sebesar 5\%, sehingga produk cacat yang terjadi masih di bawah batas toleransi.

\section{Pembahasan}

Analisis Produk Cacat

Berdasarkan hasil yang telah dijelaskan dapat kita ketahui bahwa dalam menjalankan operasional usahanya, perusahaan PT. Fajar Utama Intermedia memiliki delapan (8) orang karyawan dibidang operasional produksi dengan jam kerja delapan jam per hari selama satu minggu. Untuk mengoperasikan percetakannya, PT. Fajar Utama Intermedia menggunakan 1 mesin produksi merek goss company chikagho dengan kapasitas produksi 10.000 koran/jam serta mengunakan kertas gulungan kualitas prima dan tinta merek huber jenis CMYK.

Selama proses percetakan berlangsung, cacat atau kerusakan produk cetakan merupakan hal yang tidak bisa dihindari karena disebabkan oleh beberapa hal. Jenis kerusakan yang biasa terjadi adalah warna kabur dan posisi lipatan tidak register.

Biaya Kualitas

Berdasarkan hasil penelitian yang telah dilakukan, dapat diketahui bahwa PT. Fajar Utama Intermedia cabang Kendari telah mengeluarkan biaya kualitas. Biaya kualitas dalam hal ini, terdiri dari biaya pencegahan, biaya penilaian, dan biaya kegagalan.

Biaya pencegahan pada PT. Fajar Utama Intermedia cab. Kendari meliputi biaya perawatan dan pemeliharaan peralatan yaitu pelumasan dan perbaikan mesin. Biaya pelumasan mesin ini adalah biaya pembelian pelumas mesin produksi yang digunakan setiap kali mesin beroperasi. Pelumasan mesin ditujukan untuk menjaga kondisi 
perputaran mesin selama berproduksi, untuk keseluruhan dari cleaning hingga perbaikan total untuk biaya penggunaan mesin ini, PT. Fajar Utama Intermedia menganggarkan biaya sebesar Rp 5.000.000,00 per bulannya. Sedangkan untuk biaya pemeliharaan lainnya yaitu biaya bahan bakar generator adalah biaya bahan bakar mesin generator yang dianggarkan untuk mengantisipasi kondisi pemadaman listrik yang tentu saja dapat mengganggu proses dan kualitas percetakan, dan untuk biaya bahan bakar ini PT. Fajar Utama Intermedia menganggarkan biaya sebesar Rp 1.000.000,00 per bulannya.

Kemudian ada kegiatan pelumasan seluruh bagian dinamo motor mesin cetak. Biaya Pelumasan seluruh bagian dinamo motor mesin cetak adalah biaya yang dianggarkan untuk pegawai yang telah ditetapkan dalam kegiatannya melakukan pelumasan pada mesin cetak dimana kegiatan ini dilakukan sebanyak empat (4) kali dalam satu bulan sehingga biaya kualitas yang digunakan sebesar 4 jam x 4 kali perawatan dalam 1 bulan x Rp $30.000=\mathrm{Rp} 480.000,00$ yang terhitung sebagai kerja lembur. Menurut perusahaan yang dimaksud dengan lembur adalah kelebihan jam kerja dari waktu kerja normal yang telah ditentukan sebelumnya. Dokumen perintah lembur memang menyebutkan kegiatan yang menunjang perusahaan seperti melakukan persiapan cetak, melakukan maintenance pasca produksi, dan lain-lain yang tidak selesai pada jadwal yang telah disediakan atau memang membutuhkan pekerja yang lebih banyak sehingga beberapa pekerja terpaksa bekerja di luar waktu kerja normal mereka. Hal ini menunjukkan bahwa sebenarnya dengan pengaturan yang baik, jumlah jam kerja lembur bisa diminimalisir.

Biaya penilaian pada PT. Fajar Utama Intermedia cab. Kendari meliputi biaya inspeksi. Biaya inspeksi adalah biaya yang dianggarkan untuk pegawai yang telah ditetapkan dalam kegiatannya melakukan akifitas inspeksi atau pengecekan kembali mesin operasional percetakan setiap kali telah dilakukan percetakan. Kegiatan ini dimaksudkan untuk menjaga agar tidak ada kelainan pada kondisi mesin pecetakan, dimana kegiatan ini dilakukan sebanyak empat (4) kali dalam satu bulan sehingga biaya kualitas yang digunakan sebesar 4 jam x 4 kali perawatan dalam 1 bulan $\times$ Rp $30.000=$ Rp 480.000,00.

Biaya kegagalan internal pada PT. Fajar Utama Intermedia cab. Kendari meliputi biaya bahan sisa yaitu kerugian atas kertas sisa dan kerugian atas pemborosan tinta. Sedangkan untuk kegagalan eksternal seperti keluhan dari konsumen dan pengembalian produk sangat jarang sekali terjadi di percetakan PT. Fajar Utama Intermedia sehingga tidak dicatat.

Analisis Biaya Kualitas dalam Upaya Mengurangi Produk Cacat pada PT. Fajar Utama Intermedia

Dari pengamatan dan pengumpulan data yang dilakukan, telah sesuai dengan pendapat (Hansen \& Mowen, 1994:398) yang menyatakan bahwa suatu perusahaan dengan pengelolaan kualitas yang dapat berjalan dengan baik biayanya tidak lebih $2,5 \%$ dari penjualan. Diketahui bahwa tingkat produk cacat (misdruk) yang terjadi cukup tinggi, untuk pencetakan surat kabar Kendari Pos Rp 1.120.000/hari, diikuti oleh Rakyat Sultra sebesar Rp 480.000/hari, Kolaka Pos dan Radar Buton sebesar masing-masing Rp 384.000/hari, dan yang terkecil adalah Berita Kota sebesar Rp 288.000/hari. Total biaya kualitas yang dikeluarkan atas jumlah produk yang cacat sebesar Rp17.410.000 atau $0,84 \%$ dari total penjualan sebesar $\mathrm{Rp} 2.080 .000 .000$ per bulan. Tingginya angka kecacatan produk tentunya menjadi sebuah kerugian bagi perusahaan karena akan menciptakan pemborosan.

Maka dari itu, sebagai langkah awal dalam program perbaikan kualitas, perusahaan perlu menyusun laporan biaya kualitas yang memberikan sebuah perkiraan 
adanya konsekuensi keuangan dari tingkat cacat produk yang ada di perusahaan. Karena di dalam laporan biaya kualitas yang telah disusun terlihat berbagai biaya yang telah dikeluarkan oleh perusahaan, sehingga manajemen dapat menggunakannya sebagai perencanaan dalam total biaya yang akan dikeluarkan berikutnya, dapat melakukan kontrol terhadap biaya yang dikeluarkan sehingga penyimpangan-penyimpangan dapat diminimalkan dan pihak manajemen dapat melakukan pengambilan keputusan untuk mengambil tindakan yang diperlukan untuk digunakan sebagai perbaikan kualitas selanjutnya.

Perusahaan membutuhkan suatu tindakan yang dapat mengatasi permasalahan tersebut. Sedangkan tindakan pencegahan (preventive maintenance) dan tindakan penilaian (appraisal maintenance) yang berlaku hanya sebatas pemeliharaan rutin sederhana seperti adanya inspeksi dan perawatan harian seperti pembersihan, pelumasan dan pengencangan komponen mesin. Dengan kata lain jika perusahaan lebih meningkatkan tindakan pencegahan dan tindakan penilaian dengan mengalokasikan sejumlah biaya pada kedua hal tersebut maka akan diikuti dengan menurunnya ju mlah produk cacat dan biaya kegagalan yang menjadi semakin rendah. Hal ini disebabkan karena biaya pencegahan dan biaya penilaian adalah biaya yang dikeluarkan oleh perusahaan untuk mencegah kualitas yang buruk atas produk yang dihasilkan. Ketika suatu perusahaan mengalokasikan sejumlah biaya untuk tindakan pencegahan dan penilaian, hal ini menunjukkan bahwa perusahaan tersebut sudah berupaya melakukan tindakan pengendalian atas produk cacat.

Dengan penelusuran lebih lanjut mengenai biaya kualitas yang telah digunakan pada perusahaan percetakan PT. Fajar Utama Intermedia cab. Kendari kemudian dapat disusun rekomendasi usulan tindakan atau upaya yang bisa dilakukan oleh perusahaan untuk menekan tingkat misdruk yang terjadi, salah satunya yaitu meningkatkan kualitas SDM (Sumber Daya Manusia) dapat dilakukan dengan cara melakukan pengawasan atas para pekerja dengan lebih ketat dan memberikan pelatihan kepada para pekerja serta membuat sistem penilaian kerja yang baru dengan tujuan untuk memotivasi kinerja para pekerja agar lebih baik. Maka dari itu dengan adanya laporan biaya kualitas pihak manajemen dapat membuat perencanaan, pengevaluasian dan keputusan berdasarkan laporan biaya kualitas tersebut, terutama dalam tindakan menurunkan produk cacat. Hasil ini cukup untuk dapat membuka pandangan perusahaan untuk meningkatkan kinerja manufakturnya terutama dalam hal melakukan pengendalian kualitas produksi secara total agar secara konsisten dapat menghasilkan produk yang berkualitas dengan menekan tingkat kecacatan menjadi serendah mungkin.

\section{KESIMPULAN, IMPLIKASI, KETERBATASAN DAN REKOMENDASI}

1. Kesimpulan

Berdasarkan hasil penelitian dan pembahasan yang dikemukakan sebelumnya, maka dapat diambil kesimpulan yaitu PT. Fajar Utama Intermedia cab. Kendari telah mengeluarkan biaya kualitas ialah perawatan preventif yang terdiri dari pelumasan seluruh bagian dinamo motor mesin cetak dan inspeksi, biaya penggunaan bahan supplies yang terdiri dari pelumasan mesin dan bahan bakar generator serta biaya sisa bahan baku yang terdiri dari pemborosan kertas dan tinta. Upaya yang bisa dilakukan perusahaan dalam mengurangi produk cacat pada penggunaan biaya kualitas adalah perusahaan perlu menyusun laporan biaya kualitas kemudian melakukan suatu tindakan dengan meningkatkan biaya pencegahan dan biaya penilaian dengan mengalokasikan sejumlah biaya pada kedua hal tersebut sehingga akan menurunkan jumlah produk cacat dan membuat biaya kegagalan menjadi semakin rendah. Salah satunya adalah meningkatkan kualitas SDM seperti memberikan pelatihan kepada 
Jurnal Akuntansi dan Keuangan (JAK)

Volume 5, Nomor 2 Tahun 2020

Page: 307 - 317

http://ojs.uho.ac.id/index.php/jak-uho

e-ISSN: 2088-4656

pekerja. Perusahaan harus melakukan pengendalian kualitas produksi secara total agar secara konsisten dapat menghasilkan produk yang berkualitas dengan menekan tingkat kerusakan menjadi serendah mungkin.

2. Implikasi

Penggunaan biaya kualitas khususnya mengalokasikan sejumlah biaya pada biaya pencegahan dan biaya penilaian dapat meningkatkan kualitas produk yang akan berdampak pada menurunnya jumlah produk cacat. Salah satunya dengan mengantisipasi faktor penyebab terjadinya produk cacat. Diharapkan dengan adanya biaya kualitas perusahaan bisa melakukan pengendalian produk cacat sehingga dapat meningkatkan volume penjualan perusahaan yang akan meningkatkan pendapatan dan profit perusahaan.

3. Keterbatasan penelitian

Perusahaan tidak membuat laporan biaya kualitas secara khusus sehingga penulis mengklasifikasikan elemen-elemen biaya kualitas sendiri. Biaya pencegahan hanya mencakup biaya perawatan atau pemeliharaan mesin cetak. Biaya penilaian hanya mencakup biaya pemeriksaan atau inspeksi. Biaya kegagalan internal hanya mencakup biaya sisa bahan karena perusahaan tidak melakukan pengerjaan ulang pada produk yang cacat. Tidak terdapat biaya kegagalan eksternal di PT Fajar Utama Intermedia karena perusahaan tidak menyediakan biaya-biaya yang terdapat dalam biaya kegagalan eksternal karena pengembalian produk sangat jarang sekali terjadi di percetakan PT. Fajar Utama Intermedia.

4. Rekomendasi

Berdasarkan hasil penelitian serta berdasarkan analisis data yang telah dilakukan, maka penulis memberikan saran dengan harapan dapat berguna bagi perusahaan dan peneliti selanjutnya, yaitu :

1. Perusahaan sebaiknya membuat laporan biaya kualitas secara khusus (tersendiri) dengan diklasifikasikan kedalam golongan biaya kualitas, agar dapat terlihat dengan jelas komponen dari masing-masing biaya kualitas.

2. Perusahaan diharapkan dapat memberi perhatian dan mengalokasikan sejumlah biaya yang dimiliki pada biaya kualitas yang terdiri dari biaya pencegahan dan biaya penilaian, karena kedua biaya tersebut apabila semakin dinaikkan maka dapat mengurangi jumlah produk cacat.

3. Perusahaan perlu mengantisipasi faktor penyebab terjadinya produk cacat dari ke empat unsur-unsur penyebab.

4. Bagi peneliti selanjutnya, penelitian dapat dilakukan pada perusahaan yang memiliki data mengenai biaya kualitas dan produk cacat yang memadai, sehingga diperoleh hasil penelitian yang lebih akurat.

\section{DAFTAR PUSTAKA}

Carter. William K. 2009. Akuntansi Biaya. Buku 1. Edisi Keempat Belas. Jakarta: Salemba Empat. 
Jurnal Akuntansi dan Keuangan (JAK)

Volume 5, Nomor 2 Tahun 2020

Page: 307 - 317

http://ojs.uho.ac.id/index.php/jak-uho

e-ISSN: 2088-4656

Feigenbaum, A.V. 2013. Kendali Mutu Terpadu. Jakarta : Erlangga.

Dunia, Firdaus Ahmad dan Wasilah Abdullah. 2012. Akuntansi Biaya Edisi Ketiga, Jakarta: Salemba Empat.

Hansen, Don R., Mowen, Maryanne M. 2009. Managerial Accounting; Akuntansi Manajerial, Buku 2 Edisi Kedelapan. Jakarta: Salemba Empat.

Hansen, Don R., Mowen, Maryanne M. 2013. Akuntansi Manajemen. Terjemahan Dewi Fitriasari dan Deny Arnos Kwary.. Jakarta: Salemba Empat.

Harnanto. 2017. Akuntansi Biaya: Sistem Biaya Historis. Yogyakarta: BPFE.

Horngren, Charles T. 2008. Akuntansi Biaya Manajerial. Jilid 1. Edisi Sebelas. Jakarta: PT. Indeks

Krismiaji, Aryani Y. Anni. 2011. Akuntansi Manajemen. Edisi Kedua. Yogyakarta : STIE YKPN

Mulyadi. 2010. Sistem Akuntansi Cetakan Kelima. Edisi Ketiga. Jakarta: Salemba Empat

Mulyadi. 2015. Akuntansi Biaya. Edisi Kelima. Yogyakarta : STIE YKPN

Samryn, L.M. 2012. Akuntansi Manajemen Informasi Biaya untuk Mengendalikan Aktivitas Operasi dan Investasi. Jakarta: Kencana

Supriyono, R.A. 2011. Akuntansi Biaya: Pengumpulan Biaya dan Penentuan Harga Pokok Produksi. Edisi Kedua. Yogyakarta: BPFE.

Susilowati. 2011. Reaksi Signal Profitabilitas dan Solvabilitas Terhadap Return Saham

Perusahaan. Jurnal Dinamika Keuangan dan Perbankan, Vol 3, No. 1, Mei 2011 : 6,16) 